\title{
Evaluating the ecotoxicity of different pharmaceuticals using Aliivibrio fischeri bioassays
} https://doi.org/10.21698/rjeec.2020.107

Original research

\section{LUCIAN IONESCU, STEFANIA GHEORGHE*, DANIEL MITRU, CATALINA STOICA, ALINA ROXANA BANCIU, MADALINA MIHALACHE, MIHAI NITA-LAZAR}

National Research and Development Institute for Industrial Ecology ECOIND, 71-73, Drumul Podu Dambovitei Str., Bucharest, Romania.

* corresponding author (e-mail): stefania.gheorghe@incdecoind.ro

\section{Abstract}

An endless list of companies has produced a large amount of pharmaceutical compounds in a year-on-year growth trend. Due to the excessive consumption of these substances and the inappropriate disposal, the environment was contaminated, especially aquatic ecosystems, with quantities of pharmaceuticals (PHACs) so that they have affected the living organisms, leading to decreased biodiversity and ecological degradation.

Many studies on PHACs environmental presence and toxic effects were performed, but unfortunately, no limit was establishing for discharging into environment, especially into the aquatic systems. The aim of this study was to use the bioluminescence of Aliivibrio fischeri bacteria as an indicator of toxical effect of different PHACs in simulated marine medium. The Microtox ${ }^{\circledR}$ bioassay is based on the PHACs inhibitory effect on the metabolism of bacteria which induced changes in their bacterial bioluminescence.

The test organisms were exposed to analgesics and anti-inflammatories such as Diclofenac, Ketoprofen, Naproxen and Ibuprofen. The results showed that based on EC50 values, Naproxen had a very low toxicity but Diclofenac, Ketoprofen and Ibuprofen had a harmful effect on the aquatic organisms.

Keywords: bioassay, pharmaceuticals, Aliivibrio fischeri, bioluminescence

\section{Introduction}

Over the last century the cause of synthesized chemicals dissemination into environment have been triggered by massive industrialization and anthropogenic activities [1]. Among the chemicals, pharmaceuticals (PHACs) have been of a particular interest due to their properties to remain biological active for long periods and to have the potential to produce toxic effects in concentrations above a certain limit $[2,3]$.

Their development and use in human and veterinary medicine had led to a significant reduction in mortality and morbidity rates, targeting significant infectious diseases such as syphilis, tuberculosis, gonorrhea, pneumonia and communicable childhood diseases [4].

The European Union (EU) is the second biggest consumer of PHACs in the world (24\% of the world total) after the U.S.A. Consumption of human and veterinary PHACs is mostly heterogeneous across the EU Member States, for example, it ranges from 50 to $150 \mathrm{~g} /$ capita/year in the case of human consumption PHACs. Moreover, in the majority of EU, a large part of unused human PHACs (50\% on average) has been not collected and some EU Member States have not implemented take-back schemes [5]. In spite of their benefic effects, PHACs have been also identified as an emerging class of environmental contaminants due to their overuse as well as their complex system of bioaccumulation and transformation [4]. The spread of PHACs in freshwater systems, contributes to a global dissemination and a development of multi-drug resistance organisms. This phenomenon is the most important challenge for the health care sector in the $21 \mathrm{st}$ century [4]. The number of the studies concerning the presence of PHACs in aquatic environments have increased in last decades. Some monitoring studies of pharmaceutical residues concentrations in international surface waters showed a concentration of $8-80 \mathrm{ng} / \mathrm{L}$ PHACs in Finland [6]; 1.1 - $61 \mathrm{ng} / \mathrm{L}$ in South Korea [7]; 0.5 - $620 \mathrm{ng} / \mathrm{L}$ in Taiwan [8]; 1 $2098 \mathrm{ng} / \mathrm{L}$ in China [9]. Other studies highlighted different concentration ranges of some pharmaceutical compounds in the Waste Water Treatment Plants (WWTPs) effluents such as Diclofenac $(0.289 \mu \mathrm{g} / \mathrm{L})$ and Ibuprofen 
$(2.972 \mu \mathrm{g} / \mathrm{L})$ [10]; Naproxen $(0.017 \mu \mathrm{g} / \mathrm{L})$ and carbamazepine $(0.042 \mu \mathrm{g} / \mathrm{L})$ [11].

Their massive presence into the environment have generated concerns that were addressed by numerous studies that assessed and estimated their environmental risks. However, PHACs potential toxicity in aquatic systems and ultimately in humans remains in a great measure in a state of uncertainty. As a result, PHACs are not controlled by current European water quality standards or European laws, which require evidence of their environmental contamination and intrinsic risk. An integrated approach to current sources of PHACs released into the environment, the interaction between environment and substances, their capacity to decompose and their remanence in the environment and, significantly, the risks they present are particularly important in order to be able to predict and regulate these substances in the environment [12]. PHACs were originally designed to act on specific targets in human body, but, nevertheless, there are many published studies that indicate indirect effects on organisms for which the substances were not intended [13, 14] such as Naproxen on Eisenia andrei [15] and Ketoprofen on Daphnia magna [16].

In Romania, an investigation was carried out on the Somes River where fifteen PHAC compounds including stimulants, antirheumatics, antiepileptics, analgesics, anticoagulants were detected in concentrations ranging from $30 \mathrm{ng} / \mathrm{L}-10 \mu \mathrm{g} / \mathrm{L}$ [17]. In another research project were identified amounts of PHACs at levels of 57 to $270 \mathrm{ng} / \mathrm{L}$. These levels were determined from the water at the entrance to a treatment plant in Romania. This situation exist because low metabolic rate conversion in the human and animal organisms and inefficient removal in urban wastewater treatment plants $[1$, $16,18]$.

A large amount of data is available concerning the monitoring of PHACs in surface water bodies such as rivers, lakes, and marshlands [19, 20], but these are not centralized or in a standardized format. Environmental PHACs concentrations were low or missing for some environment components, notably for biota in the food web and marine ecosystems [19]. As a consequence of the discharge of continental water into the marine environments, some
PHACs will likely end up in the seas and oceans and certainly there is a need to increase the knowledge about their occurrence in such ecosystems [20]. Over time, different organisms from the affected areas (and not only) were used as biological material (biological models) so that, as a result, the obtained data could be extrapolated either to a certain general category of organisms, either on a human level. Most methods are based on the following categories: fish, algae, crustaceans, insects, aquatic plants, bacteria. Each of these organisms has characteristics that make them suitable for certain tests depending on the topic of interest or the expected result [13].

Within the biological methods developed in the last decades, bacterial tests have become particularly well known for being simple, fast, and inexpensive, with good correlations with other toxicity tests responses, including with superior organisms. As a result, bacterial bioluminescence inhibition tests are usually the first choice for testing potential toxicity of PHACs from environmental samples [21, 22]. Overall, PHACs could induce an acute and chronic toxic effect in aquatic species, bio accumulate in ecosystems and decrease their biodiversity $[12,21]$.

Toxicity tests (bioassays) were used in last decades to assess whether a chemical compound or waste present in the environment could affect living organisms. Acute and chronic tests are most known ecotoxicity bioassays. The acute toxicity bioassays use organisms such as mammals, algae, daphnia, fish, bacteria and even cell cultures [13, 23].

This kind of tests are often used to do a rapid toxicity assessment or to determine the relative sensitivity of different organisms. The chronic toxicity tests are more complex and require more time than do the previous tests. Moreover, chronic toxicity tests are designed to obtain information on teratogenicity or carcinogenesis, and other types of information that are collected during life cycles of particular species. One of the principal advantages of acute toxicity tests in nonmammalian species is that these organisms have biochemical routes similar to those of the higher organisms, short life cycles, and respond promptly to changes in their living medium [23, 24]. 
In this study, we tested the PHACs toxic effect by a luminescent bacteria test using Aliivibrio fischeri Microtox ${ }^{\circledR}$ toxicity bioassay. This

\section{EXPERIMENTAL PART}

The toxic effect of PHACs on the environment was analyzed by biotests with bioluminescent bacteria A. fischeri. This method associated the toxic effect with the degree of bioluminescence inhibition, and it was performed according to a standard method [26] with lyophilized bacteria. In short, lyophilized A. fischeri NRRL B-11177 luminescent bacteria (purchased from Modern Water), stored at temperature lower than $-18^{\circ} \mathrm{C}$, was activated then incubated for 30 minutes in absence and presence of various concentrations of PHACs.

The blank control was prepared from $20 \mathrm{~g} / \mathrm{L}$ $\mathrm{NaCl}$ ( $\mathrm{pH}$ between 6.0-8.5 $\mathrm{pH}$ units) and it was used as a control of the optimal growth conditions.

To evaluate the sensitivity of bacteria a reference test using $100 \mathrm{mg} / \mathrm{L}$ potassium dichromate (Merck, CertiPUR ${ }^{\circledR}$ ) was performed (positive control). The test was considered positive control, which induced $20 \%$ to $80 \%$ inhibition after a contact time of $30 \mathrm{~min}$. method has received special attention due to its simplicity, sensitivity, reliability, and low cost $[21,22,25]$.

$100 \mathrm{mg} / \mathrm{L}$ was the maximum concentration tested for each pharmaceutical compound such as Diclofenac, Ibuprofen, Naproxen and Ketoprofen. The inhibitory effect of the PHACs could be determined as effective concentration (EC) such as $\mathrm{EC}_{50}$ values (sample concentration which results in an inhibition of light intensity of $20 \%$ and $50 \%$, respectively) by means of dilution series.

The bioluminescence inhibition (\%) and $\mathrm{EC}_{50}$ values and their graphical representation were automatically generated by MicrotoxOmni software from the Microtox ${ }^{\circledR}$ M500 equipment (in acute mode). The assays were performed in replicate for each dilution.

The substances used for testing were widely used analgesics and anti-inflammatory drugs; all chemicals were purchased from Sigma-Aldrich (Merck, Germany; purity >98\%), as following: Diclofenac (sodium salt), Ketoprofen (Ventranal), Naproxen (Ventranal), Ibuprofen (Table.1).

Table 1. Analgesics and anti-inflammatory drugs [27] used in present Microtox ${ }^{\circledR}$ bioassay

\begin{tabular}{|c|c|c|c|c|}
\hline Name & IUPAC name & CAS & Structure & $\begin{array}{l}\text { Molecular } \\
\text { Formula }\end{array}$ \\
\hline $\begin{array}{l}\text { Diclofenac } \\
\text { sodium salt }\end{array}$ & $\begin{array}{c}\text { Sodium }\{2-[(2,6- \\
\text { dichlorophenyl)amino]phenyl }\} \text { acetate }\end{array}$ & $15307-79-6$ & & $\mathrm{C}_{14} \mathrm{H}_{11} \mathrm{Cl}_{2} \mathrm{NNaO}_{2}$ \\
\hline Ketoprofen & 2-(3-Benzoylphenyl)propanoic acid & 22071-15-4 & & $\mathrm{C}_{16} \mathrm{H}_{14} \mathrm{O}_{3}$ \\
\hline Naproxen & $\begin{array}{l}\text { (2S)-2-(6-Methoxy-2- } \\
\text { naphthyl)propanoic acid }\end{array}$ & 22204-53-1 & & $\mathrm{C}_{14} \mathrm{H}_{14} \mathrm{O}_{3}$ \\
\hline Ibuprofen & 2-(4-Isobutylphenyl)propanoic acid & $15687-27-1$ & & $\mathrm{C}_{13} \mathrm{H}_{18} \mathrm{O}_{2}$ \\
\hline
\end{tabular}

\section{RESULTS AND DISCUSSION}

The acute toxicity tests were performed on $A$. fischeri as a biological model. A. fischeri had a normal metabolic activity in presence of $20 \mathrm{~g} / \mathrm{L}$ $\mathrm{NaCl}$, and, the reference substance (potassium dichromate) inhibited the metabolism which could be detected between 20 and $80 \%$ inhibition of luminescence. The results on potassium dichromate showed a $50 \%$ inhibition $\left(\mathrm{EC}_{50}\right)$ induced at a concentration of $16.2 \mathrm{mg}$ $\mathrm{Cr} / \mathrm{L}$ (Fig. 1); this value is close to that specified 
in the standard method $(18.7 \mathrm{mg} \mathrm{Cr} / \mathrm{L})$. That was method and the viability of bacterial strains. performed for checking the validity of the

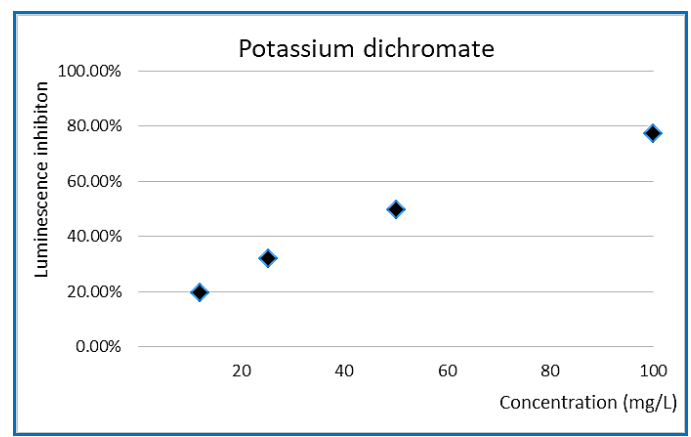

Fig. 1. Bioluminescence inhibition induced by potassium dichromate on A. fischeri.

The $\mathrm{NaCl}$ and potassium dichromat demonstrated that A. Fischeri bacterial strain was the viable and optimally respond to the chemical compounds. The next step of the experimental part was to analyze the toxic effect of other chemical compounds such as PHACs (Diclofenac, Ibuprofen, Naproxen and Ketoprofen).

The analgesics and anti-inflammatory drugs induced a wide range of toxicity, depending on their concentrations (Fig 2). Ketoprofen had the highest toxic effect, totally inhibiting the luminescence at $40 \mathrm{mg} / \mathrm{L}$ (Fig. 2B). Inhibition curve of ketoprofen showed a sharp toxic effect compared to other PHACs. At a concentration of $100 \mathrm{mg} / \mathrm{L}$, only Diclofenac (Fig. 2A) induced 100\% inhibition, Ibuprofen reached $80 \%$ inhibition and Naproxen had a relative small toxic effect, inhibiting only $40 \%$.

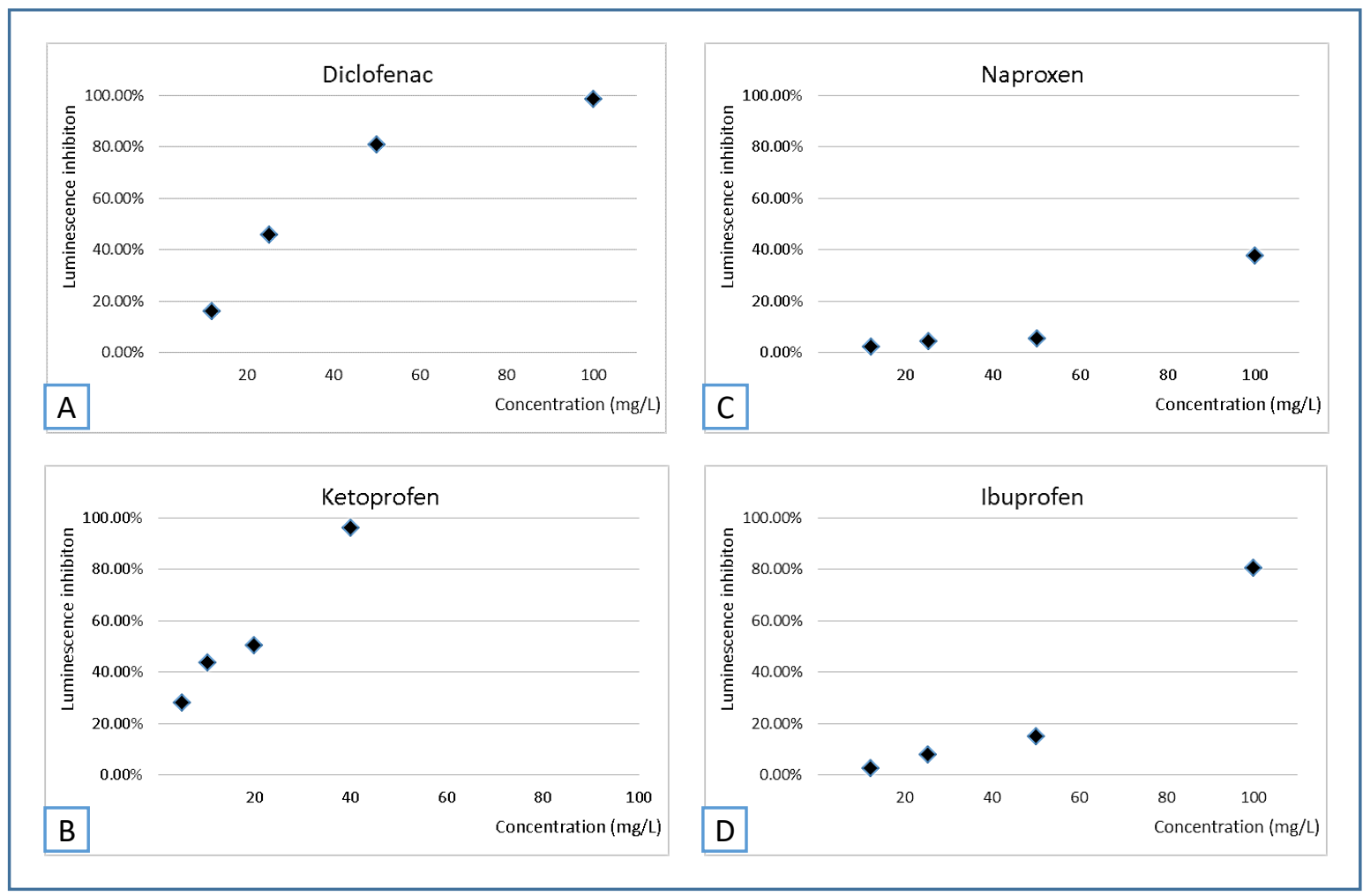

Fig. 2. Bioluminescence inhibition induced by four PHACs on A. fischeri: A) Diclofenac, B) Ketoprofen, C) Naproxen, D) Ibuprofen.

In the following paragraphs, we discuss each of PHACs separately. In the table no. 2 was introduced the name of substance, the concentrations range tested, $\mathrm{EC}_{50}$, the confidence interval of $95 \%$ and the coefficient of determination. 
Table 2. EC50 (30 min) data of PHACs on A. fischeri.

\begin{tabular}{c|cccc}
\hline $\begin{array}{c}\text { Substance } \\
\text { name }\end{array}$ & $\begin{array}{c}\text { Concentrations } \\
\text { interval tested } \\
(\mathrm{mg} / \mathrm{L})\end{array}$ & $\begin{array}{c}\mathrm{EC}_{50}(30 \mathrm{~min}) \\
(\mathrm{mg} / \mathrm{L})\end{array}$ & $\begin{array}{c}\text { Confidence range } \\
(95 \%) \\
(\mathrm{mg} / \mathrm{L})\end{array}$ & $\begin{array}{c}\text { Coefficient of } \\
\text { determination } \\
\left(\mathrm{R}^{2}\right)\end{array}$ \\
\hline Diclofenac & $12.5-100$ & 20.62 & $13.49-31.52$ & 0.9730 \\
Ketoprofen & $5-40$ & 11.61 & $10.28-33.08$ & 0.9711 \\
Naproxen & $12.5-100$ & $>100$ & - & 0.8884 \\
Ibuprofen & $12.5-100$ & 64.41 & $36.24-83.30$ & 0.9240 \\
\hline
\end{tabular}

Diclofenac had a $50 \%$ inhibitory effect at 20.62 $\mathrm{mg} / \mathrm{L}\left(\mathrm{EC}_{50}\right)$ which is in the same concentration range as it was described in other studies, $\mathrm{EC}_{50}$ $22.9 \mathrm{mg} / \mathrm{L}$ [28], $16.31 \mathrm{mg} / \mathrm{L}$ or $11.79 \mathrm{mg} / \mathrm{L}$ [14]. Ketoprofen had an $\mathrm{EC}_{50}$ of $11.61 \mathrm{mg} / \mathrm{L}$, very similar low concentration with a high toxic effect to other studies where EC $_{50}$ was detected at $16.21 \mathrm{mg} / \mathrm{L}$ [16]. A possible explanation could be that chemical structure of ketoprofen is more likely to "lose" a benzene nucleus from its structure in metabolic processes [29], having the ability to combine with other radicals resulting in more toxic compounds.

A lower inhibitory effect was observed for two of the chemicals tested, Naproxen and Ibuprofen, The results obtained for ibuprofen showed an $\mathrm{EC}_{50}$ at $64.41 \mathrm{mg} / \mathrm{L}$ in spite of other studies showing that was $39.89 \mathrm{mg} / \mathrm{L}$ [16].

Naproxen had a small inhibitory effect, under $50 \%$, but there were studies showing an $\mathrm{EC}_{50}$ value of $53.35 \mathrm{mg} / \mathrm{L}$ [14]. However, EC $\mathrm{C}_{50}$ values for naproxen were in a large range from 19.95 [16] to $53.35 \mathrm{mg} / \mathrm{L} \mathrm{[14].} \mathrm{An} \mathrm{explanation} \mathrm{about}$ low inhibitory effect of Naproxen may be that the naphthalene nucleus inside the structure is not split into the cell and, as a result, no

\section{CONCLUSIONS}

This study provides the ecotoxicological data of four drugs in simulated marine medium. A. fischeri biological model presented a good and reproducible sensibility for the PHACs in the assay. The PHACs tested (Diclofenac, Ibuprofen, Naproxen and Ketoprofen) showed that there was a dependent relationship between secondary metabolic products more toxic will be generated. Moreover, the degradation of naproxen in monosubstrate conditions occurred with a low efficiency [30].

The coefficient of determination for all PHACs tested shows that inhibition of bioluminescence is directly correlated with the concentration, but slightly lower for Naproxen because of the weak inhibition response. Regarding the confidence interval, it could only be established for three of the four PHACs tested. Because of lower inhibitory response for naproxen, it could not be establish any confidence range for it.

Ecotoxicity of the tested PHACs was compared with Passio and Smith method: extremely toxic $\left(\mathrm{EC}_{50}<0.1 \mathrm{mg} / \mathrm{L}\right)$, highly toxic $(0.1-1.0 \mathrm{mg} / \mathrm{L})$, moderately toxic $(1-10 \mathrm{mg} / \mathrm{L})$, slightly toxic $(10-100 \mathrm{mg} / \mathrm{L})$, practically harmless $(100-1000$ $\mathrm{mg} / \mathrm{L}$ ) and relatively harmless (> $1000 \mathrm{mg} / \mathrm{L}$ ) [23]. Given these EC50 intervals, we can characterize the tested substances as follows:

- Diclofenac, Ketoprofen and Ibuprofen with $\mathrm{EC}_{50}$ in a range of $10-100 \mathrm{mg} / \mathrm{L}$ are slightly toxics ("harmful to the aquatic organisms" [31]). - Naproxen with $\mathrm{EC}_{50}>100 \mathrm{mg} / \mathrm{L}$ is practically harmless.

concentration and the toxic effect, the coefficient of determination being greater than 0.8 . The highest inhibitory effect was induced by Ketoprofen $\left(\mathrm{EC}_{50}\right.$ of $\left.11.61 \mathrm{mg} / \mathrm{L}\right)$ then by Diclofenac $\left(\mathrm{EC}_{50}\right.$ of $\left.22.62 \mathrm{mg} / \mathrm{L}\right)$, Ibuprofen $\left(\mathrm{EC}_{50}\right.$ of $\left.64.41 \mathrm{mg} / \mathrm{L}\right)$, and Naproxen $\left(\mathrm{EC}_{50}\right.$ not calculated).

\section{ACKNOWLEDGEMENTS}

This work was financially supported by Nucleu Program SMARTWAY (Reference: PN 190402 01, contract no. 20N/2019) from the Romanian National Authority for Scientific Research and Innovation CNCS/CCCDI-UEFISCDI. 


\section{REFERENCES}

[1] COSTA, F., LAGO, A., ROCHA, V., BARROS, O., COSTA, L., VIPOTNIK, Z., SILVA, B., TAVARES, T., Environ. Sci. Technol., 53, no. 13, 2019, p. 7185.

[2] WANG, D., WU, X., LIN, Z., DING, Y., Environ. Res., 162, 2018, p. 127, https://doi.org/10.1016/j.envres.2017.12.015.

[3] LI, J.J., ZHANG, X.J., YANG, Y., HUANG, T., LI, C., SU, L., ZHAO, Y.H., CRONIN, M.T.D., Sci. Total. Environ., 616-617, 2018, p. 491,

https://doi.org/10.1016/j.scitotenv.2017.10.308.

[4] CARVALHO, I.T., SANTOS, L., Env. Int., 94, 2016, p. 736.

[5] TIWARI, B., SELLAMUTHU, B., OUARDA, Y., DROGUI, P., TYAGI, R.D., BUELNA, G., Biores. Tech., 224, 2017, p. 1, http://dx.doi.org/10.1016/j.biortech.2016.11.042 [6] KIM, S.D., CHO, J., KIM, I.S., VANDERFORD, B.J., SNYDER, S.A., Water Res., 41, no. 5, 2007, p. 1013.

[7] CHEN, H.-C., WANG, P.-L., DING, W.-H., Chemosphere, 72, no. 6, 2008, p. 863.

[8] PENG, X., YU, Y., TANG, C., TAN, J., HUANG, Q., WANG, Z., Sci. Total Environ., 397, no. 1-3, 2008, p. 158.

[9] ROBERTS, P.H., THOMAS, K.V., Sci Total Environ, 356, no. 1-3, 2006, p. 143.

[10] MC AVOY, D.C., SCHATOWITZ, B., JACOB, M., HAUK, A., ECKHOFTF, W., Environ. Toxicol. Chem., 21, no. 7, 2002, p. 1323.

[11] LIN, W.C., CHEN, H.C., DING, W.H., J. Chromatogr A, 1065, no. 2, 2005, p. 279.

[12] BARANAUSKAITE-FEDOROVA I., DVARIONIENE J. AND NIKIFOROV V. A., Water Sci. Technol., 74, no. 6, 2016, p. 1255.

[13] WESTLUND, P., NASUHOGLU, D., ISAZADEH, S., YARGEAU, V., Arch. Environ. Contam. Toxicol., 74, no. 4, 2018, p. 557.

[14] DOKMECI, A.H., DOKMECI, I., IBAR, H., Environ. Process., 1, no. 2, 2014, p. 95.

[15] JALLOULI, N., ELGHNIJI, K., HENTATI, O., RIBEIRO A.R., SILVA, A.M.T., KSIBI, M., J Haz. Mat., 304, 2016, p. 329.

[16] GHEORGHE, S., PETRE, J., LUCACIU, I., STOICA, C., NITA-LAZAR, M., Environ. Monit. Assess., 188, no. 6, 2016, p. 379.

[17] MOLDOVAN, Z., Chemosphere, 64, no. 11, 2006, p. 1808.
[18] PETRE, J., IANCU, V.I., NICULESCU, M., VASILE, G.-G., International Symposium "The Environment and the Industry" SIMI 2013, Volume II, Bucharest, Romania, p. 111, http://www.simiecoind.ro/wp-

content/uploads/2015/04/SIMULTANEOUSDETERMINATION-OF-\%CE\%92-

LACTAMS-ANTIBIOTICS.pdf.

[19] BIO Intelligence Service (2013), Study on the environmental risks of medicinal products, Final Report prepared for Executive Agency for Health and Consumers. Available from: https://ec.europa.eu/health/sites/health/files/files/ environment/study_environment.pdf

[08.05.2020]

[20] MORENO-GONZALEZ, R., RODRIGUEZ-MOZAZ, S., GROS, M., BARCELO, D., LEON, V.M., Environ. Res., 138, 2015, p. 326.

[21] JARQUE, S., MASNER, P., KLANOVA, J., PROKES, R., BLAHA, L., Front. Microbiol., 7, 2016, https://doi.org/10.3389/fmicb.2016.01738. [22] RODRIGUES, J.M., LASA, B., APARICIO-TEJO, P.M., GONZÁLEZMURUA, C., MARINO, D., Sci. Total Environ., 624, 2018, p. 1180, https://doi.org/10.1016/j.scitotenv.2017.12.241. [23] LOMBA, L., LAPENA, D., ROS, N., ASO, E., CANNAVO, M., ERRAZQUIN, D., GINER, B., Environ. Sci. Pollut. Res., 27, no. 9, 2020, p. 9891.

[24] THE NATIONAL ACADEMIES OF SCIENCES, ENGINEERING, AND MEDICINE. Application of Modern Toxicology Approaches for Predicting Acute Toxicity for Chemical Defense, National Academies Press (US), Washington (DC), 2015, Assays for Predicting Acute Toxicity. Available from: https://www.ncbi.nlm.nih.gov/books/NBK32142 4/ [04.05.2020].

[25] HUANG, G., CAO, T., SUN, S., BI, Q., LI, P., Toxicol. Environ., Chem. 99, no. 5-6, 2017, p. 848.

[26] SR EN ISO 11348-3:2019 - Water quality. Determination of the inhibitory effect of water samples on the luminescence of Vibrio fischeri (Luminescent bacteria test). Part 3: Method with lyophilized bacteria.

[27] https://www.chemspider.com/ 
[28] OSORIO, V., SANCHIS, J., ABAD, J.L., [30] WOJCIESZYNSKA, D., GUZIK, U., Appl. GINEBREDA, A., FARRE, M., PEREZ, S., Microbiol. Biotechnol., 104, no. 5, 2020, p. BARCELO, D., J. Haz. Mat., 309, 2016, p. 157.1849.

[29] DOMARADZKA, D., GUZIK, U., [31] ZUR, J., PINSKI, A., MARCHLEWICZ, WOJCIESZYNSKA, D., Rev. Environ. Sci. A., HUPERT-KOCUREK, K., Biotechnol., 14, 2015, no. 2, p. $229 . \quad$ WOJCIESZYNSKA, D., GUZIK, U., Environ. Sci. Pollut. Res. Int., 25, no. 22, 2018, p. 21498. 